Artikel Penelitian

\title{
Hubungan Faktor Risiko dengan Fungsi Kognitif pada Lanjut Usia Kecamatan Padang Panjang Timur Kota Padang Panjang
}

\author{
Iqbal Al Rasyid ${ }^{1}$, Yuliarni Syafrita ${ }^{2}$, Susila Sastri $^{3}$
}

\begin{abstract}
Abstrak
Kemajuan teknologi dan industri berdampak kepada peningkatan kualitas kesehatan. Tujuan penelitian ini adalah menentukan hubungan faktor risiko seperti pertambahan usia, jenis kelamin, stresor sosial, tingkat pendidikan, penyakit yang pernah diderita dan pekerjaan terhadap fungsi kognitif lanjut usia. Penelitian dilakukan dengan studi potong lintang menggunakan data hasil Tes MoCA-Ina. Penelitian dilakukan di kecamatan Padang Panjang Timur pada tahun 2014. Hasil analisis data dengan chi-square didapatkan bahwa sebagian besar responden adalah usia lanjut $(60,8 \%)$, berjenis kelamin perempuan $(71,1 \%)$, memiliki tingkat pendidikan rendah $(61,9 \%)$, dan tidak memiliki riwayat penyakit (gangguan kardiovaskular, diabetes, kejang, dan trauma kepala) $(51,5 \%)$. Analisis bivariat didapatkan usia dengan fungsi kognitif ( $p=0,001$ ), jenis kelamin dengan fungsi kognitif ( $p=0,100)$, tingkat pendidikan dengan fungsi kognitif $(p=0,017)$, dan riwayat penyakit dengan fungsi kognitif $(p=0,394)$. Hasil penelitian ini dapat disimpulkan bahwa terdapat hubungan bermakna antara usia dan tingkat pendidikan terhadap fungsi kognitif lanjut usia. Pada jenis kelamin dan riwayat penyakit tidak terdapat hubungan bermakna.
\end{abstract}

Kata kunci: kognitif, lanjut usia, faktor risiko

\section{Abstract}

The advanced of industrial and technology affect the improvement of health care quality. The objective of this study was to determine the correlation among risk factors such as age, gender, social stressors, education level, previous illnesses and work on cognitive impairment in elderly. The study was conducted with a cross-sectional study using data from MoCA-Ina test. The study was held in district Padang Panjang Timur in 2014. The population target was elderly aged same or above 60 years. Method of sample selection was simple random sampling with 97 samples. Data analysis with Chi-Square method shows that most of respondents are elderly (60.8\%), female (71.1\%), have a low education level (61.9\%), and without previous illnesses (cardiovascular disease, diabetes, convulsive, and head trauma) (51.5\%). Bivariate analysis between age and cognitive function in the elderly $(p=0.001)$, gender and cognitive function ( $p=0.100$ ), education level and cognitive function $(p=0.017)$, and previous illness with cognitive function $(p=$ 0.394). It is concluded that there is a significant relationship between cognitive function with age and education level, but not with gender and previous illnesses.

Keywords: :cognitive, eldery, risk factors

Affiliasi penulis: 1. Prodi Profesi Dokter Fakultas Kedokteran Universitas Andalas Padang, 2. Bagian IImu Saraf FK Unand. 3. Bagian Biokimia FK Unand

Korespondensi:Iqbal AI Rasyid, email: arzt_rasyid@live.com, Telp: 083180869698

\section{PENDAHULUAN}

Teknologi dan industri yang mengalami peningkatan pada abad ke-20 ini berdampak positif terhadap peningkatan kualitas sarana prasarana kesehatan, pengetahuan di bidang kesehatan, dan peningkatan tingkat higenitas perorang. Kemajuan di bidang kesehatan berdampak pada peningkatan usia 
harapan hidup. Bertambahnya usia harapan hidup mengakibatkan peningkatan jumlah lanjut usia. ${ }^{1,2}$

Lanjut usia dapat sangat tergantung pada orang lain, baik dalam masalah ekonomi maupun masalah aktifitas dan kegiatan fisik. Hal ini dapat terjadi karena proses yang ditandai dengan perubahan fisik-biologis, mental ataupun psikososial. Kebanyakan yang menjadi fokus masalah pada lanjut usia adalah masalah psikologi atau masalah mental, diantaranya adalah dalam perilaku sosial, behavior dan dalam mengurus kebutuhan sehariannya. ${ }^{3}$

Perubahan mental yang dialami lanjut usia diantaranya perubahan kepribadian, memori dan perubahan intelegensi. Perubahan ini dapat terjadi akibat pengaruh beberapa hal, diantaranya; perkembangan dunia, pertambahan usia, faktor geografis, jenis kelamin, kepribadian, stresor sosial, dukungan sosial, dan pekerjaan. ${ }^{4}$ Seiring dengan pertambahan jumlah lanjut usia maka dokter dilayanan primer akan sering mendapatkan masalah gangguan fungsi kognitif pada lanjut usia.

Bentuk gangguan kognitif ringan yang menjadi perhatian praktisi dan peneliti adalah Mild Cognitive Impairment $(\mathrm{MCl}), \mathrm{MCl}$ dalam perjalanan klinisnya beresiko tinggi menjadi demensia atau Alzheimer dengan rasio $10-12 \%$ per tahun. Diperkirakan dengan rasio tersebut dalam 3-4 tahun separuh dari subjek $\mathrm{MCl}$ akan menjadi demensia atau Alzheimer. ${ }^{5}$ Prevalensi kejadian $\mathrm{MCl}$ pada negara industri sekitar $10-25 \%$ yang terjadi pada populasi diatas 65 tahun. Beberapa faktor risiko kardiovaskular, seperti diabetes, hiperlipidemia, dan hipertensi juga memiliki hubungan dengan gangguan atau penurunan fungsi kognitif melalui interaksi komplek faktor risiko tersebut dengan perubahan seluler otak dan kognitif. $^{6}$ Peningkatan keluhan dan resiko gangguan fungsi kognitif, maka deteksi dini untuk gangguan fungsi kognitif.

Peningkatan keluhan dan resiko gangguan fungsi kognitif, maka deteksi dini untuk gangguan fungsi kognitif semakin penting. Semakin dini dideteksi, maka kemungkinan terapi menjadi lebih efektif. Dalam klinik neurologi, pengamatan dari fungsi kognitif didapatkan dari pengamatan perilaku yang secara meluas. Pengamatan perilaku tersebut dilakukan dimulai dari yang sederhana hingga yang kompleks sehingga didapatkan kesimpulan dan gambaran tentang keadaan susunan saraf. ${ }^{7}$

Penilaian fungsi kognitif dengan pemeriksaan neuropsikologis merupakan kunci utamanya. Pemeriksaan fungsi kognitif yang cukup populer diantaranya adalah Tes Mini Mental State Examination (MMSE). Cara penilaian lainnya adalah dengan Montreal Cognitive Assesment (MoCA) yang berasal dari Kanada. ${ }^{8}$ Husein et al pada tahun 2009 juga mengatakan Tes MoCA merupakan tes yang paling sensitif dalam mendeteksi gangguan fungsi kognitif. Menurutnya Tes MoCA versi Indonesia (MoCA-Ina) dapat diaplikasikan untuk menilai fungsi kognitif di Indonesia dan merupakan instrumen yang valid. ${ }^{9}$

Jumlah lanjut usia yang semakin meningkat, tersedianya instrumen untuk menilai fungsi kognitif, serta belum terdapatnya penelitian mengenai faktor risiko yang mempengaruhi fungsi kognitif pada lanjut usia di daerah Padang Panjang Timur membuat peneliti tertarik untuk melakukan penelitian ini sehingga gangguan fungsi kognitif lanjut usia dapat dideteksi lebih awal.

\section{METODE}

Penelitian ini merupakan studi cross sectional dengan menggunakan data dari hasil Tes MoCA-Ina pada lanjut usia yang berada di kota Padang Panjang, kecamatan Padang Panjang Timur. Populasi target pada penelitian ini adalah lanjut usia yang berusia $\geq 60$ tahun. Populasi terjangkaunya (accesible population) adalah lanjut usia yang berusia $\geq 60$ tahun yang berada di kota Padang Panjang, kecamatan Padang Panjang Timur pada bulan November 2013 - Mei 2014.

Prinsip yang dipakai untuk mengambil sampel adalah probability sampling dengan cara Simple Random Sampling. Besar sampel diambil dari populasi menggunakan rumus dan didapatkan besar sampel 97 orang. 
HASIL

Tabel 1. Distribusi frekuensi responden berdasarkan usia, jenis kelamin, tingkat pendidikan, riwayat penyakit, dan fungsi kognitif

\begin{tabular}{|c|c|c|c|}
\hline No & Karakteristik & Frekuensi & $\%$ \\
\hline \multirow[t]{4}{*}{1} & Usia & & \\
\hline & a. Usia Lanjut & 59 & 60,8 \\
\hline & b. Tua & 38 & 39,2 \\
\hline & c. Sangat Tua & 0 & 0 \\
\hline \multirow[t]{3}{*}{2} & Jenis Kelamin & & \\
\hline & a. Laki-laki & 28 & 28,9 \\
\hline & b. Perempuan & 69 & 71,1 \\
\hline \multirow[t]{2}{*}{3} & Tingkat Pendidikan & & \\
\hline & $\begin{array}{l}\text { a. Pendidikan Rendah } \\
\text { b. Pendidikan Tinggi }\end{array}$ & $\begin{array}{l}60 \\
37\end{array}$ & $\begin{array}{l}61,9 \\
38,1\end{array}$ \\
\hline \multirow[t]{3}{*}{4} & Riwayat Penyakit & & \\
\hline & $\begin{array}{l}\text { a. Memiliki Riwayat } \\
\text { Penyakit }\end{array}$ & $\begin{array}{l}47 \\
50\end{array}$ & $\begin{array}{l}48,5 \\
515\end{array}$ \\
\hline & $\begin{array}{l}\text { b.Tidak Memiliki Riwayat } \\
\text { Penyakit }\end{array}$ & & \\
\hline \multirow[t]{4}{*}{5} & Fungsi Kognitif & & \\
\hline & a.Kognitif Terganggu & 64 & 66,0 \\
\hline & b. Normal & 33 & 34,0 \\
\hline & Jumlah & 97 & 100 \\
\hline
\end{tabular}

Penelitian ini mendapatkan sebagian besar responden adalah usia lanjut yaitu 59 (60,8\%), sebagian besar responden berjenis kelamin perempuan yaitu 69 (71,1\%). Berdasarkan tingkat pendidikan yang diimiliki dapat diketahui bahwa sebagian besar responden memiliki tingkat pendidikan rendah yaitu 60 (61,9\%). Sedangkan pada riwayat penyakit yang dimiliki didapatkan bahwa sebagian besar responden tidak memiliki riwayat penyakit yaitu $50(51,5 \%)$.

Tabel 2. Hubungan usia dengan fungsi kognitif pada lanjut usia

\begin{tabular}{lcccccc}
\hline $\begin{array}{c}\text { Jenis } \\
\text { Kelamin }\end{array}$ & $\begin{array}{c}\text { Kognitif } \\
\text { Terganggu }\end{array}$ & \multicolumn{2}{c}{$\begin{array}{c}\text { Kognitif } \\
\text { Normal }\end{array}$} & p & $\begin{array}{c}\text { Odd } \\
\text { Ratio }\end{array}$ \\
& $\mathbf{f}$ & $\%$ & $\mathbf{f}$ & $\%$ & & \\
\hline Perempuan & 49 & 71,0 & 20 & 29,0 & \multirow{2}{*}{0,100} & 2,123 \\
Laki-laki & 15 & 53,6 & 13 & 46,4 & & \\
\hline Jumlah & 64 & 66,0 & 33 & 34,0 & & \\
\hline
\end{tabular}

Pada Tabel 2 terlihat tidak terdapat hubungan bermakna antara jenis kelamin dengan fungsi kognitif pada lanjut usia, meskipun perempuan memiliki kemungkinan mengalami gangguan kognitif 2,123 kali lebih berisiko dibanding laki-laki. Namun perbedaan ini tidak bermakna secara statistika berdasarkan hasil analisa Chi Square dengan $p>0,05$.
Tabel 3. Hubungan jenis kelamin dengan fungsi kognitif pada lanjut usia

\begin{tabular}{|c|c|c|c|c|c|c|}
\hline \multirow{3}{*}{ Usia } & \multicolumn{4}{|c|}{ Fungsi Kognitif } & \multirow{3}{*}{$\begin{array}{c}\text { Nilai } \\
\text { p }\end{array}$} & \multirow{3}{*}{$\begin{array}{l}\text { Odd } \\
\text { Ratio }\end{array}$} \\
\hline & \multicolumn{2}{|c|}{$\begin{array}{c}\text { Kognitif } \\
\text { Terganggu }\end{array}$} & \multicolumn{2}{|c|}{$\begin{array}{c}\text { Kognitif } \\
\text { Normal }\end{array}$} & & \\
\hline & f & $\%$ & f & $\%$ & & \\
\hline Tua & 33 & 86,8 & 5 & 13,2 & & \\
\hline $\begin{array}{l}\text { Usia } \\
\text { Lanjut }\end{array}$ & 31 & 52,5 & 28 & 47,5 & 0,001 & 5,961 \\
\hline Jumlah & 64 & 66,0 & 33 & 34,0 & & \\
\hline
\end{tabular}

Berdasarkan Tabel 3 didapatkan bahwa usia tua lebih banyak mengalami gangguan kognitif yaitu $33(86,8 \%)$ dibandingan dengan responden yang usia lanjut $31(52,5 \%)$. Perbedaan ini bermakna sesuai hasil analisa chi-square didapatkan nilai $p<0,05$. Berarti ada hubungan bermakna antara usia dengan fungsi kognitif pada lanjut usia dengan odd ratio sebesar 5,961.

Tabel 4. Hubungan tingkat pendidikan dengan fungsi kognitif pada lanjut usia

\begin{tabular}{ccccccc}
\hline Pendidikan & \multicolumn{3}{c}{$\begin{array}{c}\text { Fungsi Kognitif } \\
\text { Tegnitif }\end{array}$} & $\begin{array}{c}\text { Kognitif } \\
\text { Normal }\end{array}$ & p & $\begin{array}{c}\text { Odd } \\
\text { Ratio }\end{array}$ \\
\hline & $\mathbf{f}$ & $\%$ & $\mathbf{f}$ & $\%$ & & \\
\hline $\begin{array}{c}\text { Pendidikan } \\
\text { Rendah }\end{array}$ & 45 & 75,0 & 15 & 25,0 & & \\
$\begin{array}{c}\text { Pendidikan } \\
\text { Tinggi }\end{array}$ & 19 & 51,4 & 18 & 48,6 & & \\
\hline Jumlah & 64 & 66,0 & 33 & 34,0 & & \\
\hline
\end{tabular}

Berdasarkan Tabel 4 didapatkan bahwa responden yang berpendidikan rendah 45 (75,0\%) lebih banyak mengalami gangguan kognitif dibandingan dengan responden yang berpendidikan tinggi 19 (51,4\%). Perbedaan ini bermakna secara statistik didapatkan nilai $\mathrm{p}<0,05$, dengan odd ratio 2,842 .

Tabel 5. Hubungan riwayat penyakit dengan fungsi kognitif pada lanjut usia

\begin{tabular}{|c|c|c|c|c|c|c|}
\hline \multirow{3}{*}{$\begin{array}{l}\text { Riwayat } \\
\text { Penyakit }\end{array}$} & \multicolumn{4}{|c|}{ Fungsi Kognitif } & \multirow{3}{*}{$\mathbf{p}$} & \multirow{3}{*}{$\begin{array}{c}\text { Odd } \\
\text { Ratio }\end{array}$} \\
\hline & \multicolumn{2}{|c|}{$\begin{array}{l}\text { Kognitif } \\
\text { Terganggu }\end{array}$} & \multicolumn{2}{|c|}{$\begin{array}{l}\text { Kognitif } \\
\text { Normal }\end{array}$} & & \\
\hline & $\mathbf{f}$ & $\%$ & $f$ & $\%$ & & \\
\hline $\begin{array}{l}\text { Memiliki } \\
\text { Riwayat } \\
\text { Penyakit }\end{array}$ & 33 & 70,2 & 14 & 29,8 & & \\
\hline $\begin{array}{l}\text { Tidak } \\
\text { Memiliki } \\
\text { Riwayat } \\
\text { Penyakit }\end{array}$ & 31 & 62,0 & 19 & 38,0 & 0,394 & 1,445 \\
\hline Jumlah & 64 & 66,0 & 33 & 34,0 & & \\
\hline
\end{tabular}


Berdasarkan Tabel 5 di atas didapatkan bahwa responden yang memiliki riwayat penyakit mengalami gangguan kognitif lebih banyak 33 (70,2\%) dibandingan dengan responden yang tidak memiliki riwayat penyakit $31(62,0 \%)$. Namun, perbedaan ini tidak bermakna secara statistik dengan $p>0,05$. Disimpulkan bahwa tidak terdapat hubungan bermakna antara riwayat penyakit dengan fungsi kognitif pada lanjut usia.

\section{PEMBAHASAN}

Jumlah usia lanjut yang lebih banyak, hal ini terkait dengan teori jam genetik dimana sebuah sel akan mati jika telah sampai pada waktunya. Hal ini terkait dengan usia harapan hidup sendiri. Berdasarkan data WHO tahun 1989 dan tahun 1995 ditemukan bahwa pada suku bangsa tertentu usia harapan hidupnya lebih tinggi dari suku bangsa yang lain. ${ }^{11}$

Berdasarkan Tabel 1, jumlah responden perempuan lebih banyak dari pada responden laki-laki. Hal ini terjadi karena usia harapan hidup perempuan lebih tinggi dibandingkan laki-laki. ${ }^{12}$ Bertambahnya usia harapan hidup mengakibatkan peningkatan jumlah lanjut usia Sehingga dengan tingginya usia harapan hidup orang yang berjenis kelamin perempuan, maka jumlah lanjut usia yang berjenis kelamin perempuan lebih banyak dibandingkan dengan lanjut usia yang berjenis kelamin laki-laki.

Tingkat pendidikan responden sebagian besar adalah pendidikan rendah. Hal tersebut terjadi karena di Indonesia penduduk lanjut usianya memiliki pendidikan yang masih relatif rendah karena presentase lanjut usia yang belum pernah sekolah atau tidak menamatkan sekolahnya lebih dari separuhnya (tidak pernah sekolah $26,84 \%$; tidak tamat SD 32,2\%), sesuai dengan hasil Susenas tahun 2012. Jumlah penduduk di pedesaan akan lebih banyak yang memiliki pendidikan yang rendah karena jenis pekerjaan di pedesaan bersifat informal dan tidak memiliki persyaratan pendidikan formal. Hal tersebut dibuktikan dengan masih tingginya presentase lansia yang bekerja di bidang pertanian. ${ }^{13}$
Sebagian besar responden tidak memiliki riwayat penyakit, riwayat penyakit yang dimaksud adalah gangguan kardiovaskular (stroke, hipertensi, vasskulitis, cardiac disease), diabetes, riwayat kejang dan trauma kepala.

Lanjut usia seharusnya memiliki banyak penyakit, hal ini terkait dengan teori penurunan cadangan fisiologis tubuh sehingga pada lanjut usia akan rentan terhadap serangan penyakit. Responden kebanyakan tidak memiliki riwayat penyakit bisa terjadi akibat banyak faktor seperti genetik, lingkungan dan gaya hidup. Selain itu, hal tersebut juga dapat terjadi akibat keterbatasan penelitian ini. Data nasional lansia pada tahun 2012 juga sejalan dengan hasil penelitian ini yang memaparkan bahwa angka kesakitan lanjut usia cukup rendah yaitu $26,93 \%$. Hal ini terjadi karena terjadinya peningkatan derajat kesehatan lanjut usia dan menurunnya angka kesakitan pada lanjut usia berdasarkan perkembangannya dari tahun 20052012. ${ }^{14}$

Seiring pertambahan usia maka akan berkurang cadangan fisiologis tubuh, sehingga makin rentan terkena penyakit. Kira-kira $5 \%$ lanjut usia akan mengalami demensia dan meningkat dua kali lipat setiap 5 tahun, pada negara industri seperti Amerika, jumlah demensia pada lanjut usia mencapai 10-15\%. Jumlah lanjut usia yang mengalami gangguan kognitif semakin berisiko ketika usia mereka makin tua, terkait juga dengan wanita yang lebih banyak mengalami gangguan kognitif lebih banyak dibandingkan wanita.

Hal ini terjadi bukan karena wanita lebih berisiko mengalami gangguan kognitif, akan tetapi karena tingginya angka harapan hidup wanita, sehingga jumlah wanita yang berusia tua itu banyak, sehingga dengan umur mereka yang tinggi akan meningkatkan risiko mereka mengalami gangguan kognitif. ${ }^{15} \mathrm{Hal}$ ini berhubungan dengan hasil penelitian berikutnya yang dapat dilihat pada Tabel 3. Pada Tabel 3 didapatkan bahwa responden yang mengalami gangguan kognitifnya lebih banyak pada responden berjenis kelamin perempuan.

Pendidikan merupakan proses menambah pengalaman hidup yang juga merupakan proses stimulasi intelektual yang akan mempengaruhi kognitif 
seseorang. Tingkat pendidikan yang rendah, berarti pengalaman mental dan lingkungannya kurang yang berdampak pada stimulasi intelektual yang kurang. Sehingga, akibatnya adalah kognitif seseorang akan buruk.

Penelitian Hartati dan Widayanti mengatakan bahwa tingkat pendidikan yang rendah merupakan salahsatu faktor risiko terjadinya gangguan fungsi kognitif contohnya pada penyakit Alzheimer. Lanjut usia, jenis kelamin perempuan, trauma kapitis berat dan faktor genetik merupakan resiko lainnya yang meningkatkan kemungkinan terjadinya penyakit Alzheimer. Penelitian tersebut mendapatkan bahwa tingkat pendidikan bukan faktor utama seseorang dapat mendapatkan skor penilaian kognitif menggunakan CDT (Clock Drawing Test), akan tetapi tingkat pendidikan akan membantu responden untuk menyelesaikan tugas dengan baik (dalam hal ini adalah dalam melakukan asesmen tersebut). ${ }^{15}$

prevalensi demensia lebih tinggi pada pasien dengan diabetes mellitus dibandingkan dengan pasien yang tidak diabetes mellitus. Juga didapatkan pada penelitian lainnya bahwa penurunan fungsi kognitif lebih cepat terjadi pada lanjut usia yang memiliki riwayat penyakit diabetes mellitus. ${ }^{16}$

Hasil penelitian untuk hubungan riwayat penyakit dengan kognitif ini berbeda dengan penelitian tersebut, hal tersebut dapat terjadi mungkin akibat berbagai faktor lainnya yang mempengaruhinya seperti lingkungan, gaya hidup (termasuk pola makan, aktifitas fisik dan stres), dan genetik. Serta penyakit yang diderita oleh lanjut usia yang tidak hanya satu penyakit saja, melainkan kumpulan dari banyak penyakit termasuk penyakit infeksi dan penyakit degeneratif.

Keterbatasan penelitian ini adalah tidak meneliti faktor tersebut (lingkungan, gaya hidup, termasuk pola makan, aktifitas fisik, stres dan genetik).

\section{SIMPULAN}

Tidak terdapat hubungan jenis kelamin dengan fungsi kognitif pada lanjut usia di Kecamatan Padang Panjang Timur Kota Padang Panjang.

Ada hubungan tingkat pendidikan dengan fungsi kognitif pada lanjut usia di Kecamatan Padang
Panjang Timur Kota Padang Panjang, dimana lanjut usia yang memiliki pendidikan rendah lebih berisiko mengalami gangguan kognitif dibandingkan lanjut usia yang memiliki pendidikan tinggi.

Tidak terdapat hubungan riwayat penyakit dengan fungsi kognitif pada lanjut usia di Kecamatan Padang Panjang Timur Kota Padang Panjang.

\section{DAFTAR PUSTAKA}

1. Timiras $P$ S. Old age as a stage of life: common terms related to aging and methods used to study. Physicological Basis of Aging and Geriatric. Edisi ke-4. New York: Informa Healtcare USA, Inc; 2007. hlm.3.

2. Hesti, Harris S, Mayza A. Pengaruh gangguan kognitif terhadap gangguan keseimbangan pada lanjut usia. Neurona: Majalah Kedokteran NeuroSains. 20081:26-31.

3. Carr D. Mid-Life and later-life crises. Encyclopedia of Gerontology. USA: Elsevier Inc; 2007.hIm.17585.

4. Radityo WE. Depresi dan gangguan tidur. Fakultas Kedokteran Universitas Udayana;1994.hlm. 2.

5. Djokosetio LS, Kusumoputro S. Memori anda setelah usia 50. Jakarta: Penerbit Universitas Indonesia; 2003.hlm.1-95.

6. Medika. Penurunan fungsi kognitif: kaitannya dengan diabetes mellitus, hiperlipidemia dan hipertensi. Medika. 2011; vol.XXXVI(3) (diunduh 08 Juni 2014). Tersedia dari: URL: HYPERLINK http://www.jurnalmedika.com.

7. Harsono. Buku Ajar neurologi klinis. Yogyakarta: Gadjah Mada University Press; 2005. hlm.3.

8. Kurniati A. Hubungan antara retinopati diabetika dengan gangguan kognitif pada penderita pasca stroke iskemik dengan diabetes mellitus (serial online) 2011 (diunduh 22 Januari 2014). Tersedia dari: URL: HYPERLINK http://eprints.undip.ac.id; 2011

9. Husein $\mathrm{N}$, Luwempouw $\mathrm{S}$, Ramli $\mathrm{Y}$. Uji validitas dan reliabilitas montreal cognitive assesment versi Indonesia (MoCA-Ina) untuk skrining gangguan fungsi kognitif. Medical Research Unit Medical Faculty University of Indonesia (serial online) 2009 
(diunduh 2 Desember 2013).Tersedia dari: URL: HYPERLINK http://mru.fk.ui.ac.id

10. Sastroasmoro S, Ismael S. Dasar-dasar metodologi penelitian klinis. Jakarta: Sagung Seto; 2002. hlm. 72-3.

11. Darmojo RB. Teori proses menua. Dalam: Martono $\mathrm{H}$, Pranarka K,editor (penyunting). Buku Ajar Boedhi-Darmojo: Geriatri (IImu Kesehatan Usia Lanjut). Jakarta: Balai Penerbit Fakultas Kedokteran Universitas Indonesia; 2009. hlm.3-9.

12. Rochmah W, Harimurti K. Demensia. Dalam: Sudoyo AW, Setiyohadi B, Alwi I,Simadibrata $M$, Setiati $S$, editor (penyunting). Buku Ajar IImu Penyakit Dalam Jilid I. Edisi Ke-5. Jakarta: Pusat Penerbitan Departemen IImu Penyakit Dalam FKUI; 2009. hlm. 837-8.
13. Kementrian Kesehatan RI. Gambaran kesehatan lanjut usia di Indonesia. Buletin Jendela; Data dan Informasi Kesehatan. Semester I.ISSN 2008-270X; 2013:1-17.

14. Kementrian Kesehatan RI. Gambaran kesehatan lanjut usia di Indonesia. Buletin Jendela; Data dan Informasi Kesehatan. Semester I. ISSN 2008270X; 2013. Hal: 1-17.

15. Hartati S, Widayanti CG. Clock drawing: asesmen untuk demensia, studi deskriptif pada orang lanjut usia di kota Semarang. Jurnal Psikologi Undip. 2010; 7(1):1-10.

16. Nasution K. Artikel penyegar; fungsi kognitif menurun akibat diabetes mellitus. Dalam Medika, Jurnal Kedokteran. 2012. Ed. 05, vol. XXXVIII(serial online) 2012. Tersedia dari: URL: HYPERLINK http://www.jurnalmedika.com 